UDC 811.161.2:81’36

DOI https://doi.org/10.32838/2663-6069/2020.4-1/19

Pedchenko S. $O$.

Poltava V. G. Korolenko National Pedagogical University

\title{
THE SUBJECTIVE MODALITY IN MODERN UKRAINIAN: THE LINGUAL-PRAGMATIC DIMENSION
}

\begin{abstract}
The article touches upon the problem of subjective modality as one of the ultimate representations of national specificity of Ukrainian. The lingual-pragmatic nature of the universalia under proof was systematically investigated. As a result, chosen theoretical-methodological integration basis revealed a further possibility of the semantic field subjective-modal stratification as well as persistent delimitation of its epistemic, volitive, and axiological constituents. In fact, the epistemic unit bares the function of core semantic fragment of subjective modality. Its semantic modelling process, categorical / problematic reliability in particular, involves the broad range of pragmarelevant explication resources, i.e. parenthetical words and clauses, comparative-hypothetical particles, modal verbatives, adverbatives, etc. This article also represents the intense disquisition of the modality of will two-component (voluntative and optative) structure, being the vivid background of versatility, diversity, multi-functionality, lack of clear boundaries between objective and subjective modes of attitude, contextual, and situational pragmatic conditionality as immanent traits of the category. It was proved, the successful differentiation of volitive concretising semes partly requires the entanglement of intra-/external-lingual factors as follows: lexical-grammatical peculiarities of a certain explicators of motivation/desirability, pragmatic presuppositions, intentions of the speaker, contextual and situational parameters, etc. Actually, the application of this approach to the above-mentioned problem's solution has its profound base in theoretical-methodological integration fundamentals, enabling a modal inventory of estimating subjective semantics disposed between two self-sufficient categories of modality and axiology. In conclusion, both rational and emotional estimations, ascertained in succession, undergo a number of concretising subsemes, parameterised on a scale "comparability / absoluteness", "reclamation / pejorativeness".
\end{abstract}

Key words: modality, subcategory modal meaning, epistemic modality, volitive modality, axiological modality.

The core problem of the issue. The integration of Ukrainian linguistics to global scientific sphere predetermines thorough philologists interest to the universal categories - locativity, temporality, concessiveness, persuasiveness, predicativity, modality, etc. The latter amongst defined above universalia takes special place at the pertaining to the humanities knowledge paradigm. It has not been being parametered yet on the methodological system basis, despite of the great amount of scientific studies on the problem.

Analysis of recent research and publications. The syntactic nature of the modality as well as its semantic structure and paradigmatic connections with other categories formed the object of grammatical studies of many linguists. They are famous Ukrainian scientists I. Vykhovanets, K. Horodenska, A. Hryshchenko, O. Melnychuk, A. Zahnitko, M. Mirchenko, M. Stepanenko, V. Shynkaruk, N. Kostusiak, etc. The modus-dictum conception of the prominent Swiss Ch. Bally correlates with generative-transformative grammars ideas. The text-centrism principle of W. Dressler, I. Halperin,
I. Smushchynska modality researches claimed to be dominant. The investigations of N. Arutiunova, O. Bondarko, A. Vezhbytska, V. Vynohradov, H. Zolotova, T. Alisova, N. Shvedova, V. Kasevych, L. Yermolaieva are the ponderable contribution to subcategory modal meanings taxonomic aspects logical qualification. Different nuances of the category under proof have been closely examined in V. Tkachuk (the subjective modality functional-semantic exposition, based on valuation category integration component), O. Dotsenko (the peculiarities of subcategory modal meanings representations via objective-ascertaining utterances), T. Teletska (the comparative analysis of objectivity and veracity modal semantics in Ukrainian, Russian, French and English), A. Matskevych (the typological parameters of modality means of realization on the base of Ukrainian and Arabic publicistic texts), S. Bernatska (the possibility and necessity modal meanings on the formal grammatical level of the sentence), and S. Skomarovska (the verbalization of modality of desirability) dissertations. 
The idea of impossibility of cognition of the nature and the essence of any linguistic unit without applying for human factor was dominant in the pastdecades global linguistics. The whole spectrum of representatives of the defined factor is embraced at the linguistic pragmatics, one of the newest pertaining to the humanities knowledge dynamic branches, science, originating at boundaries of other sciences. Nowadays Ukrainian linguistics requires for integral system of the subjective modality as wide-content filling semantic-pragmatic category, so far as the subjective constituent of the defined universalia is that to signify the synergetic correlation of three parts of semiotics (F. de Saussure, Ch. Peirce, Yu. Stepanov), which are semantics, syntactics, and pragmatics.

Aim of the research. The aim of the article is to identify the spectrum of subcategory subjective modal semantics dominant types in Modern Ukrainian, focusing on their distinct pragmatic centrism.

Results and discussions. Most of scientists agree on the point that modality content background is formed by two closely interdependent components - objective and subjective. The logical-grammatical modality interpretation platform exponents $[6 ; 8]$ comment the first component as modality de re, testifying certain peculiarities of the certain object (e.g. Сepziŭ був вихованим хлопием). The second component is determined as modality de dicto, realized in "modusdictum" structures, i.e. in sentences with explicated subjective modality (e.g. Здається, щзо Сергій вихований хлопеиь).

The objective (primary, predicative, ontological, object, deontic) modality characterizes connection between information content and extra-linguistic actuality, regarding to the speaker estimation of the first defined on the base of reality / irreality (its possibility / impossibility, desirability / undesirability, necessity / veracity). The subjective component is more complex than objective one as for the nature; therefore it has no definite determination in the theory of linguistic modality. The so-called narrow interpretation, specifying that the speaker treatment of information content is delimited by epistemic (persuasive, mental) semantics, is of priority. The subjective modality semantic spectrum, however, is much more extensive, compared to the objective one. Meanings, constituting this spectrum, are not homogeneous, requiring for systematization. Some of them have no direct connections with grammatical system. Thus, I. Nahornyi makes representatives of mental semantics the object of the investigation, elaborating the modal-persuasive qualification concept as the crossing-point of different aspects of utterancesto-actuality correlation. The logical (the ascertainment of judgment as relatively true unit), functionalsemantic (the ascertainment of fact with reference to information trustworthiness / untrustworthiness), situation (the ascertainment of speech situation on the base of its correlation to actuality), presupposition (the ascertainment of premises regarding to their speech situation correspondence / disparity), semantic (the ascertainment of proposition in accordance with its verity / fallibility), communication-pragmatic (the ascertainment of fact in compliance with its speech influence on the addressee) are the most consequential among them [12, p. 384]. This fact is a certain confirmation of some linguists traditional modality dichotomous idea negating, so far as any type of modality, especially the objective one, explicates first and foremost the attitude of the speaker (producer, author, addresser) to the utterance content. The subjectivity is modality immanent characteristic feature. It extrapolates modal semantics to the linguistic pragmatics subject field, making, on the other hand, a prospect to further formulations of the subjective modality as «semantic-pragmatic factor of communication unit and communication in general» [1, p. 191], modus category of the discourse type [13], specific meanings of which as well as their verbal actualization multi-level means form complex functional-semantic fields with identifying core and differential, partly syncretic, peripheral zones.

It is of no doubt that epistemic component is obligatory constituent of the semantic spectrum of the defined modality, though it is also correct, in our opinion, some linguists $[11 ; 5 ; 7 ; 6]$ to concretize other types of its meanings. The subjectivity of utterance, according to V. Hak, can be displayed by such three ways:

1) regarding to the character of information (declarative or performative modality);

2) regarding to the character of actuality knowledge (epistemic modality: trustworthiness, probability);

3) regarding to the character of attitude (deontic modality: desire / unwillingness, consent / disagreement) [5, p. 118].

The subjective modality, in compliance with R. Mrazek, is to be divided into two dimensions, they are 1) the meaning delimited by intention - necessity - possibility (voluntary modality); 2) the degree of the information content trustworthiness, the speaker confidence in predicate dictal core actuality (persuasive modality) [11, p. 181].

Basing on the subjective modality lingualpragmatic and communication specificity likewise 
Ukrainian past-decades scientific studies corollaries $[9 ; 20 ; 19 ; 15 ; 6 ; 1]$, we consider the defined category semantic structure accumulates the three constituents: 1) epistemic, revealing objective connections trustworthiness degree valuation of the subject of notion; 2) volitive, indicating the speaker intentions to the sentence / utterance propositional content necessity or desirability; 3) axiological, explicating the speaker valuation characterization of environment facts, represented in dictum part of the sentence.

Disquisitional studies on the problem contain wide enough subjective modality epistemic component nominating spectrum; it is "hypothetic modality" (O. Drahomyretskyi), "comparative modality" (L. Prokopchuk), "modality of seeming" (N.Arutiunova), "modalityofveracity"(V.Berezenko), "re-relating" (A. Zahnitko), "modality of doubtful valuation" (O. Seleznova) in particular. The epistemic modality essential peculiarity, we reckon, identifying with scientists majority, is to be expound by opposition on the "ordinary trustworthiness - categorical trustworthiness - problematic trustworthiness" scale. The neutral (ordinary) trustworthiness manifests fact, phenomenon or occurrence stating; the categorical one affirms intensified (accentuated) speaker confidence in the information trustworthiness. The problematic one (untrustworthiness, possibility) is concentrated on disclosing of different degree possibility of the fact, phenomenon or occurrence accomplishment from the point of view of the speaker; it also is grounded upon insufficient erudition of the subject of speech or assumption of the author, comp. Оксана поїхала до тітки; Оксана, безперечно, пойхала до тітки; Оксана, напевне, поїхала до тітки. The problematic trustworthiness represents one of the most important subjective-modal meanings, which participates in general predicative semantics forming. On the conceptual level it correlates with category of persuasiveness, semantic dimension of which is indicated by the information veracity certitude / incertitude degree marker, e.g. Вже почалось, мабуть, майбутне (L. Kostenko); Ha березі щось наче говорило (M. Vinhranovskyi); Мені здається, мамо, що вам не варто нічого казати за Мирона (V. Vynnychenko). The epistemic modality, apparently, is partly represented by grammatical modal forms (parentheses, modal verbs, comparative-hypothetic particles, etc.). The defined subjective-modal qualifiers, in J. Holmes [21] authoritative opinion, fulfill two functions in such the succession: epistemic (the explication of the speaker confidence degree about the information) and affecting (the aspiration of the addresser for benevolent communication interaction establishing and maintaining). Formally actualized uncertainty is always aimed at taking down the responsibility of author for not entirely true information representation or obviating the categorical aspect, e.g.

- Боже, та я ночами не сплю <...> Тільки про ие!! Мабуть, треба Сергія окручувати. Усе ж Тамарчин син. Кіоск мають <...> Буде мені фундамент.

- Ти $<\ldots>$ його $<\ldots>$ любиш?

- Здається < ..> Як його побачу < ..> слина у роті. Чи навпаки - пересихає.

- Це і є любов?

- Я й сама не знаю. Здається, так < ...> (Liuko Dashvar).

The producer sets the pragmatic tasks up: to explain his own sight on the situation, to report his point of view to the addressee, to require its adequate comprehension by the recipient appointing him on the correct interpretation of situation.

The volitive subjective modality likewise has distinct pragmatic orientation to extra-lingual actuality transforming, ascertaining the position of the subject of speech on the problem of proposition constituents certain objective connection necessity or desirability. Fundamental semantic dimensions of the modality under proof are voluntary (directory) and optativity. Traditional grammar specifies the first meaning as incentivity. It is qualified as request to interlocutor to operate the way, which secures actuality of the phenomenon defined by the sentence [17, p. 134], will of the speaker, transforming at certain communication situation to modal nuances of direction, order, appeal, caution, advice, desire and so on [16, p. 419]. The spectrum of voluntary explicit realizations fluctuates from insistent categorical to polite requesting, e.g. $B u \varkappa$ знаєте, щзо я ваша дочка <...> Не губіть мене! (I. Bahrianyi); Прочитайте, прошу я вас! Я вам ось і крашанок принесла! (Ostap Vyshnia); Нехай би сповістив листівкою чи переказав тобою (V. Symonenko); Добродію, добродію, чи не могли б ви меї дитини сховати? (Folk work); Та щуоб бодай тобі кістка в горло! Кахи-ках! (O. Dovzhenko). The second mentioned above meaning (optativity) is viewed by Ukrainian category grammar scientists as grammeme of the desirability mood, the latter is contamination of imperative and subjunctive moods [3, p. 262] or transformation of the subjunctive mood to the imperative [2, p. 98], e.g. Повернути б тих, кого забрало жадібне небо (porogy.zp.ua); Коли б мені отих дітей найти де-небудь (Т. Shevchenko). 
Pragma-linguistics focuses on the voluntary on the basis of speech act theory (J. Austin, J. Searle), in conformance with which there are five traditionally ascertained means of the speaker to achieve certain aim using word, i.e. types of illocutionary acts: representatives, directives, commissives, expressives, declarations. The inducement correlates with the directive speech act, intentionally centered on the addressee and his desirable to the speaker act performance. On the other hand, it causes the voluntary situation double-subjectivity - the producer as speech act subject and the recipient as causal act subject-doer obligatory actualizations. Besides, most of scientists point out that interlocutivity, contractor conductprogramming centrism, direct/mediatedmanipulating, mainly attended by emotional marker, conversationalstylistic coloration, and diverse subjective-modal nuances stratification, are the characteristic features of the imperative utterances.

Nowadays the question of the correlation of subjective modality with valuation category still is opened to discuss. Axiological category, firstly, is being interpreted as the hypercategory; it engulfs the category of modality and at the same time integrates multi-level linguistic units, which explicate positive or negative attitude to the information content [15]. The valuation, secondly, represents one of the modality types, which supplements the descriptive content of the utterance [4]. It effectuates the social-pragmatic function, partly expounding multi-layered implicit modal meanings. V. Teliia defines the axiological modality as connection, formed between the producer / recipient valuation marker and the defined reality, estimated either positive or negative on any ground according to normal "standards of things existence" in a certain picture of the world [18, p. 22-23]. The mixing of these two category universalia, in our opinion, is entailed first and foremost by the fact that majority of "modality" notion definitions contains the term "valuation" (the speaker valuation of the information content as real / unreal, trustworthy / untrustworthy, possible / impossible, etc.). The subjective-modal meanings realizations are functional doublets; at the certain context conditions they partly bear the axiological modus explicator or intensifier function, e.g. Як добре те, що смерті не боюсь $я$ я не питаю, чи тяжкий мій хрест (V. Stus); Вона скрізь $і$ завжди була гіршою, ніж я уявляв ії і творив (O. Dovzhenko). This fact doesn't contribute to these categories distinct demarcation.

Suppose that modal meanings of valuation focus at the two self-sufficing categories delimitation.
Subject obligatory manifestation as well as its attitude to the information, and valuations specificity, determined by the objective actuality, are the modality and axiological category integration features, contact zones, signifying partial, peripheral, transposition of valuation semes to the subjectivemodal ones. Rational and emotional valuations function as the only linguistics modal operators. The status of the emotional valuation has not been being set up definitely yet. Most of investigators are not unanimous on the point. Some of them eliminate the defined valuation from the modality [20], others state modal the wide spectrum of speakers emotional reactions on the occurrences and environmental phenomena $[7 ; 10]$; the third ascertain modal only the structures with emotional valuations, verbalized as comprehended (logically adapted) categories of good and evil (fortunately, out of spite, etc.) [6], e.g. Maмa, як навмисне, повільно одягається $i$, здається Степанидi, повільно йде (O. Ivanenko); За минулу добу в зоні бойових дій, на щастя, загиблих немає $<\ldots>$ (Patrioty Ukrainy, 10 chervnia 2016).

Axiological category wide interpretation predetermined the "emotional-expressive valuation" term appearing. The meaning of the defined above qualification, obviously, fills up the so-called syncretic zone too, adjoining to the category of valuation. It also assures the universally recognized linguistic idea there are no "pure" linguistic phenomena, free of the inter-category interaction. The expressiveness constitutes the semantic structure of modal utterance. It is the pragmatic component of the latter, the main task of which is to actualize certain element of the content, relegating the direction of the recipient attention. Correspondently to logical ones, we classify linguistic axiological modal meanings to comparative (explicated by "better" / "equivalent" / "worse" formulae) and absolute ("well" / "indifferently" / "bad", the comparison is not represented), e.g. $Y_{c i}$ ми хочемо стати кращими, ніж ми є насправді (O. Chornohus); Уже й Шрам із гетьманом, об'ӥхавши байрак, прискочили до того бойовища, а їй байдуже; вона плаче, вона вбивається над своїм Петрусем (P. Kulish). Emotional-expressive and rational valuations are positive (meliorative) or negative (pejorative) as for its content, moreover the content frequently can be determined by the context.

Conclusions. Thus, subjective modality is interpreted as wide-content filling semantic-pragmatic category (epistemic, volitive, axiological constituents), multilevel actualizations of which are typical representatives of the Ukrainian national identity. Modern 
Ukrainian linguistics requires for the direct semantic meanings embranchment classification of this part of the modal paradigm. Likewise it exacts the concretizing of universalia under proof symmetrical / asymmetrical connections with other categories, and subjective-modal semes multi-level materialization means qualifying simultaneously to their extrapolation into the functionalpragmatic dimension.

The subject of the pragmatics, according to Yu. Stepanov, is coherent dynamic text, correlated to the main subject, the "Ego" of the whole text, i.e. its author. Taking into consideration the defined object ontological and paradigm specificity, we perceive further scientific studies prospect in the subcategory modal meanings realizations regularity ascertainment, and their multi-level transmitters semanticfunctional conduct peculiarities research on the base of discourses of the dissimilar stylistic nature. The widest category of lingual code (discourse) specific structuring is perspective, in our opinion, on the point of succeeding research of lingual-pragmatic relevancy, polyfunctionality, and semantic-syntactic mobility of the majority of explicators of the subjective semantics nuances, differentiated above.

\section{References:}

1. Бацевич Ф. Нариси з лінгвістичної прагматики : монографія. Львів : ПАІС, 2010. 336 с.

2. Вихованець І., Городенська К. Теоретична морфологія української мови. Київ : Пульсари, 2004. 400 с.

3. Вихованець І. Частини мови в семантико-граматичному аспекті. Київ : Наукова думка, 1988. 256 с.

4. Вольф Е. Функциональная семантика оценки. Москва : КомКнига, 2006. 280 с.

5. Гак В. Теоретическая грамматика французского языка : Синтаксис. Москва : Высшая школа, 1986. 218 с.

6. Доценко О. Семантико-прагматичний синтаксис: особливості вираження модальності : монографія. Київ : Міленіум, 2006. 226 с.

7. Козловський В. Про прагматичну спрямованість суб'єктивно-оцінного аспекту модальності. Мовознавство. № 3. С. 68-73.

8. Касевич В., Храковский В. От пропозиции к семантике предложения. Типология конструкций с предикатными актантами. Ленинград : Наука, 1985. С. 9-14.

9. Космеда Т. Аксіологічні аспекти прагмалінгвістики: формування і розвиток категорії оцінки. Львів : ЛНУ ім. Івана Франка, 2000. 350 с.

10. Космеда Т. Категория оценки и категория модальности: точки соприкосновения и отличия. Bonpocbl функциональной грамматики. Гродно : ГрГУ, 2001. Вып. 4. С. 94-104.

11. Мразек Р. Дифференциация славянских языков в сфере модальности. Otazky slovanskesyntaxe : Sb. symposia "Modalni vystavba vipovedi v slovanskich jazycich". Brno, 1973. Z. III. S. 164-190.

12. Нагорный И. Персуазивная квалификация как мыслительная операция субъекта. Русский язык : исторические судьбы и современность : труды и материалы II Международного конгресса исследователей русского языка. Москва, 2004. URL: http://www.philol.msu.ru/ rlc2004/ru/decision/.

13. Ніка О. Модус у староукраїнській літературній мові другої половини XVI - першої половини XVII ст. : монографія. Київ : Київський національний університет імені Тараса Шевченка, 2009. 444 с.

14. Сафонова Н. Еволюція поглядів на суб'єктивну модальність. Вісник Львівського університету. Серія «Філологічна». 2004. Вип. 34. Ч. І. С. 74-80.

15. Старостина Ю. Интерпретация лингвистической оценки в терминах аксиологических суждений. Вестник Самарского государственного университета. 2007. № 3 (53). С. 232-241.

16. Сучасна українська літературна мова : підручник / А. Грищенко та ін. ; за заг. ред. А. Грищенка. Київ : Вища школа, 1997. 493 с.

17. Сучасна українська літературна мова : Синтаксис / за заг. ред. І. Білодіда. Київ : Наукова думка, 1972. $515 \mathrm{c}$.

18. Телия В. Коннотативный аспект семантики номинативных единиц. Москва : Наука, 1986. 143 с.

19. Ткачук В. Категорія суб'єктивної модальності : монографія. Тернопіль : Підручники й посібники, 2003. $240 \mathrm{c}$.

20. Шинкарук В. Категорії модусу і диктуму у структурі речення : монографія. Чернівці : Рута, 2002. 217 с.

21. Holmes J. Hedges and Boosters in Women's and Men's Speech. Language and Communication. № 10. P. 185-205.

\section{ПеДЧеНКО С. О. СУБ'ЄКТИВНА МОДАЛЬНІСТЬ У СУЧАСНІЙ УКРАЇНСЬКІЙ МОВІ: ЛІНГВОПРАГМАТИЧНИЙ ВИМІР}

У статті йдеться про суб'єктивну модальність як один із найяскравіших виявів національної специфіки украӥнської мови. Особливу увагу зосереджено на лінгвопрагматичній природі досліджуваноі універсалії. Запропоновані інтеграційні теоретико-методологічні засади дали змогу авторові стра- 
тифікувати суб'єктивно-модальне значеннєве поле, виокремити в його складі епістемічний, волітивний і аксіологічний сегменти. Ядерним змістовим фрагментом суб'єктивної модальності ідентифіковано епістемічний, моделювання семантики якого, зокрема категоричної / проблематичної достовірності, відбувається із залученням широкого кола прагмарелевантних експлікаційних ресурсів (вставні і вставлені компоненти, порівняльно-гіпотетичні частки, модальні вербативи, адвербативи тощо). У розвідиі також удокладнено схарактеризовано двокомпонентну структуру (волюнтатив і оптатив) модальності волевиявлення, на тлі якої найвиразніше відбиваються такі іманентні ознаки досліджуваної категорії, як універсальність, різноаспектність, поліфункційність, відсутність чітких кордонів між об'єктивним і суб'єктивним модусами, контекстна й ситуативна прагматична зумовленість тощо. Доведено, що розмежування конкретизувальних сем волітивності потребує почасти врахування внутрішньо- $і$ зовнішньолінгвальних чинників, а саме: лексико-граматичної специффіки конкретних експлікаторів спонукальності / бажальності, прагматичних пресупозицій, інтенцій мовия, контекстуально-ситуативних параметрів тощь. Зреалізований підхід до задекларованої у статті проблеми, базований на інтеграційних теоретико-методологічних засадах, уможливив модальну інвентаризацію оцінних суб 'єктивних значень, щзо зосереджені на покордонні двох самодостатніх категорій (модальності й аксіологічності). Виокремлені в запропонованій студї раціанальна й емоційна оцінки також мають низку конкретизувальних значень, параметризованих за шкалою компаративність / абсолютність, меліоративність / пейоративність.

Ключові слова: модальність, субкатегорійне модальне значення, епістемічна модальність, волітивна модальність, аксіологічна модальність. 